\title{
Between the Managerial and the Democratic University: Governance Structure and Academic Freedom as Sites of Political Struggle
}

\author{
DALIE GIROUX \\ University of Ottawa, Canada \\ DIMITRIOS KARMIS \\ University of Ottawa, Canada \\ CHRISTIAN ROUILLARD \\ University of Ottawa, Canada
}

\begin{abstract}
In this article we argue that the university cannot fully contribute to democratic life without being both an institution whose governance is collegial and based on principles of equality, equity, inclusion, transparency, and accountability, and a vector of critical thinking closely linked to academic freedom. Based on this understanding of the 'democratic university,' we seek to highlight some of the key tensions between the 'managerial university' and the democratic university, as reflected in institutional structures, regulations, legal frameworks, and principles. In order to achieve this objective, we identify two sites of political struggles from which it is possible to examine the interaction between a managerial and a democratic conception and practice of the university. The first of these sites is the bicameral governing structure, membership, rules, and regulations of the University of Ottawa. The second site is academic freedom in Canada, which we will discuss by comparing the Canadian Association of University Teachers' (CAUT) Statement on Academic Freedom (CAUT, 2011) with the Association of Universities and Colleges of Canada's (AUCC) Statement on Academic Freedom (AUCC, 2011). By stressing the necessary link and positive relationship between democratic governance and academic freedom, the article offers a normative evaluation of the impact the managerial reengineering of Canadian universities has had on the possibility and practice of a more democratic university.
\end{abstract}

KEYWORDS university governance; academic freedom; managerialism; democratic university

Correspondence Address: Dalie Giroux, School of Political Studies, University of Ottawa, Ottawa, ON, Canada, K1N 6N5; Email: dalie.giroux@uottawa.ca

ISSN: $1911-4788$ 
Over the past ten years, contemporary universities have gone through major conflicts, including the strike initiated by teaching and research assistants at New York University in 2005-2006, the student strike of Vienna in 2009, the opposition movement against the Loi relative aux libertés et responsabilités des universités (LRU) in France in 2009, and the student strike in Quebec in 2012. Each of these protests has advanced simultaneously a critique of the 'neoliberal university' and the claim for a 'democratic university.'

Corporatization is at the heart of the neoliberal conception of the university, which has become dominant since the 1990s (Chan \& Fisher, 2008; Côté \& Allahar, 2011; Côté, Day \& de Peuter, 2007; Ginsberg, 2011; Giroux \& Karmis, 2015; Mills, 2012; Readings, 1996; Turk, 2000). Managerialism - here understood as the ideological proposition that articulates practices of corporatization (Rouillard, 2003) - would have universities reproducing practices and cultures found in the corporate world. These include, as examples, the centralization of decision-making, the hierarchical professionalization of administrative positions and relations (including those typically held by professors; see Ginsburg, 2011), an organizational culture of secrecy, and superficial consultations with faculty, staff, and students about the direction of the university. Managerialism also comes with a strong focus on international growth and rankings, an increased reliance on private funding, massive investments in advertising campaigns, and the use of normative markers such as "excellence" (Readings, 1996, pp. 21-43) and "best practices" (Ginsburg, 2011, p. 12; Bissonnette \& Porter, 2013, p. 27) to describe goals and the means to achieve them. Consequently, a rift has widened within the university between senior management on the one side, and 'employees' and 'clients' on the other.

In this article we argue that the university cannot contribute effectively to democratic life without being both an institution whose governance is collegial and based on principles of equality, equity, inclusion, transparency, and accountability (i.e., democratic governance), and a vector of critical thinking closely linked to academic freedom. Based on this understanding of the democratic university, and rooted in Critical Managerial Studies (CMS) (Hudon \& Rouillard, 2015), this article seeks to highlight some of the key tensions between the 'managerial university' and the democratic university, as reflected in institutional structures, regulations, legal frameworks, and principles. It offers a normative evaluation of the impact the managerial reengineering of Canadian universities has had on the possibility and practice of a more democratic university.

In order to achieve this objective, we identify two sites of political struggle from which it is possible to examine the interaction between a managerial and a democratic conception and practice of the university. The first of these sites is the bicameral governing structure, membership, rules, and regulations of the University of Ottawa, focusing on the limited and circumscribed presence of professors and students, as well as the strong presence of administrative (internal) and corporate (external) representatives on both the Board of 
Governors and the Senate. Based on this case, we argue that the managerial turn of the university has been made possible in part by top-down methods of appointment that make these two key decision-making bodies highly unrepresentative. The lopsided character of these bodies enables the rise of authoritarian governance in universities, and therefore represents a serious challenge to the influence of collegial governance.

The second site of political struggle between the managerial and democratic modes of university governance we wish to examine is academic freedom. We do this by comparing the Canadian Association of University Teachers' Statement on Academic Freedom (CAUT, 2011) with the Association of Universities and Colleges of Canada's Statement on Academic Freedom (AUCC, 2011). ${ }^{1}$ The two statements differ significantly in their perspectives, reflecting a serious gap between how a confederation of faculty associations and the body representing university administrations view academic freedom. We exemplify some of these differences briefly with recent Canadian cases that raise questions about university management's treatment of academic freedom. We argue that academic freedom is a central component of a democratic university and explain how it is threatened by managerialism. We explain how asymmetrical bicameralism, in the context of managerialism, fosters the stranglehold of financial management over academic administration, further marginalizing professors, students and support staff, as well as posing a growing threat to democratic and collegial governance. None of these developments is unavoidable or unstoppable, as a university's central decision-making bodies, namely its Board of Governors and Senate, are the locus of ideological tensions and political struggles, both within and amongst themselves. Before investigating our specific cases, we turn to a brief description of the managerial turn in university governance.

\section{The University and the Managerial Turn}

In recent years, universities in Ontario, as well as elsewhere in Canada and around the world, have called into question not only their modes of operation, but also their mission and raison d'être. This questioning has taken shape within a socio-political context of fiscal austerity and is articulated through the prism of public spending reduction under the guise of innovation, performance, and efficiency. Over the past 25 years, Ontario universities have seen a significant reduction in public funding, ${ }^{2}$ which has necessitated alternative sources of revenues in order to maintain and strengthen current levels of teaching and research. These revenues have come primarily in the

\footnotetext{
${ }^{1}$ AUCC changed its name to Universities Canada on April 22, 2015.

2 According to the Ontario Confederation of University Faculty Associations (OCUFA, 2015), after the 2015 Ontario Budget per-student university funding in Ontario reached its lowest level since the 1960s. See HEQCO $(2015,6)$ for the evolution of government grants as a share of operating fund revenue for Ontarian universities, from 1970-71 to today.
} 
form of private funding, such as tuition fees, philanthropy, and corporate donations (Council of Ontario Universities, 2012). Despite reductions in public funding, universities are required to fulfill ever-expanding responsibilities, as outlined in the multi-annual agreements initiated by the Government of Ontario in 2006.

Similar to the core public sector in many industrialized countries during the 1980s (Pollitt \& Bouckaert, 2011), universities fell under the influence of managerialism during the late 1990s. Managerialism is first and foremost an ideological movement: a set of beliefs, preferences, attitudes, actions, and values, articulating the idea that individual relations, issues, and resources of all kinds need to be properly managed in order to achieve the optimal output (Enteman, 1993; Exworthy \& Halford, 1999; Rouillard \& Giroux, 2005). Within managerialism, communities, citizens, and in the case of universities, students, have all become clients whose specific needs and desires need to be shaped and managed by a cast of 'experts.' Increasingly, these experts are permanent career managers, not faculty holding a temporary administrative position. Performance management and measurement are at the forefront of managerial organizations. Importantly, managerialism's emphasis on quantitative goals and results (i.e., output), understood in this context as an accountability mechanism, can only come at the expense of procedural fairness, and transparency, whose qualitative nature excludes them from being quantified.

The 'managerialization' of universities, which continues unabated in Ontario, is reflected in the proliferation of planning, control, measurement, and evaluation activities, ${ }^{3}$ occasionally combined with more or less credible consultation processes. Paradoxically, however, this managerial process marginalizes the role of teaching and research in the daily lives of those who actually give life to the university, namely full- and part-time professors. The 'community service' component of faculty members' jobs, which occupies an increasing part of their typical workload, seems to have less and less to do with any community per se, and more and more to do with control, measurement, and evaluation tasks and responsibilities.

At the centre of the Canadian managerial university are its main decisionmaking bodies, the Senate and Board of Governors. In the following section we examine the context of appointments to these bodies at the University of Ottawa, to show how it enables the rise of managerialism in academia.

\footnotetext{
${ }^{3}$ As an illustration amongst many others, a 2011 report from the Council of Ontario Universities (COU), Innovative Ideas - Improving Efficiency at Ontario Universities, has proposed five managerial actions to increase efficiency in Ontario universities: (1) streamlining operational processes, (2) innovation and partnerships, (3) managing facilities efficiently, (4) making smart purchasing decisions and (5) planning for safety (Council of Ontario Universities, 2011).
} 
The University of Ottawa's Bicameralism: A Sober Second Look at the Board of Governors and Senate

Founded in 1848 under the name College of Bytown, the University of Ottawa as it exists today was created through an act established by the Ontario government in 1965. This organic law, ${ }^{4}$ the 1965 University of Ottawa Act (Government of Ontario, 1965), established the institution's bicameral governance structure and set out its functional division of responsibilities and separation of powers between the Board of Governors (financial and budgetary function) and the Senate (academic function).

This bicameral system is based on a dichotomy between financial management and academic administration, which supposes the existence of easily identifiable and sealed boundaries between the two spheres. In practice this is not the case, as academic decision-making inevitably has budgetary impacts, and most budgetary decisions have consequences for academic life. Nevertheless, the dichotomy as it is practised results in the overrepresentation of administrative, corporate, and financial representatives on both the Board of Governors and Senate. The member profile of these two decision-making bodies and their respective methods of appointment reinforce this binary between the academic and financial management spheres. According to the organic law of the university full-time professors are guaranteed representation in the Senate (at least one professor per faculty), but not on the Board of Governors; faculty involvement is not considered essential to the university's financial decision-making.

No rule prevents adequate or even majority representation of full-time and part-time faculty members, support staff, or graduate and undergraduate students on the Board of Governors, as (a) by regulation and law the Board of Governors is responsible for appointing 12 of its members, and up to 4 additional individuals to reach its maximum of 32 members; and (b) the Senate nominates 2 members (from among its members) to the Board of Governors. The remaining 14 members are appointed by the Government of Ontario (4 members), the Alumni Association ( 2 members), and the Council of Administration of Saint Paul University ( 8 members). In practice, however, the presence of faculty, staff, and students on the Board of Governors and its financial sub-committees is severely limited.

Unlike the Board of Governors, the Senate is composed mainly of exofficio members, and according to the organic law of the university there is no limit to the number of members it can appoint. ${ }^{5}$ However, the method of nominating professors is key: each professor is appointed by the council of his/her faculty (which consists of the Dean, Vice-Deans, the Secretary, all

\footnotetext{
${ }^{4}$ Put simply, an organic law is the foundational law of an organization such as a university, and encompasses its main functions, attributes, and responsibilities. Constitutions and by-laws are examples of organic laws.

${ }^{5}$ There are currently 82 members on Univertisy of Ottawa's Senate. See:

http://web5.uottawa.ca/admingov/senat-membres.html (last accessed August 31st, 2015).
} 
department and school heads, as well as a fixed and limited number of professors), rather than elected by peers. This affects the Senate's legitimacy in terms of democratic representation, and creates potential obstacles for prospective candidates should they be assessed negatively or be in conflict with their Dean or Vice-Dean. For professors, this is a barrier to organizational commitment, as a professor cannot become a member of the Senate through election by his or her peers.

Following the adoption of new regulations in 2008, the number of Senate members was considerably increased in order to include undergraduate students (one per faculty) and two graduate students from across the university, as well as four associate Vice-Presidents, two Deans, one ViceDean, the Registrar, the Chief Librarian, and the Directors of various learning support services. Any impact the appointment of students may have had was diluted by the proliferation of new administrators. The 2008 regulations also add to Senate one professor per faculty, to be elected by their respective Faculty Council, except in faculties where an Associate Dean or Vice-Dean exists to fill the position. Increasing the number of students and faculty has not been sufficient to change their minority status - and therefore reduce their marginalization - on Senate, even though it is the decision-making body responsible for academic matters.

Managerial control over the appointment process also means that neither the Association of Professors of the University of Ottawa (APUO) nor any other union or student association can appoint a representative to the Board of Governors or Senate. While this is the norm in Ontario universities, there are notable exceptions: St. Thomas University, Laurentian University, University of Hearst at Timmins, and Ryerson University. In these four Ontarian universities, the Faculty Association (i.e., the union that represents faculty members and academic librarians) can directly appoint one or more member to the Senate. While one can argue as to which is preferable, being appointed by the union or being elected by peers, the point is that neither of these two methods of appointments has ever been possible in most universities in Ontario and, as far as we know, in Canada.

The challenges of the University's bicameral governance do not stop there. Under current interpretation the University's organic law (Government of Ontario, 1965), the Board of Governors and Senate are linked through a highly asymmetrical relationship, where the financial management prerogative of the former curtails the academic administration of the later. With the exception of awarding degrees and diplomas, and adopting its own rules of governance, all of the attributes and powers of the Senate have a direct financial impact, which means that the resulting decisions are subject to approval by the Board of Governors. In others words, through its financial management prerogative, the Board of Governors directly influences academic administration, which has de facto become a shared responsibility between the Board of Governors and the Senate. Academic administration is 
no longer the prerogative of the Senate, as initially intended by the sharing of responsibilities that comes with bicameral assemblies.

The current makeup of the University of Ottawa's Board of Governors is certainly reflective of managerial influence; in addition to the President and Chancellor, two-thirds of its members (20 out of 31 ) are managers and senior executives within the private, public, and semi-public sectors, whereas only four members are professors, two are support staff, and two are undergraduate and graduate students. The makeup of the Executive Committee of the Board of Governors, which exercises the Board's powers between meetings, also reflects the rise of managerialism in academia. Eight out of 12 members are external to the university, while only three are internal members (one administrator from the Office of the Vice-President, External Relations, a graduate student, and one professor), along with the President. Among these eight external members, five come from the private sector, including lobbying, management consulting, and media companies. ${ }^{6}$

Despite the Senate's academic mission, faculty are again heavily outvoted: only 16 of 82 members are faculty. In other words, the two main decisionmaking bodies of the University of Ottawa are beyond the control of those who contribute directly to teaching and research (part-time and full-time professors, and support staff), and those who are directly affected by the quality of teaching and research (undergraduate and graduate students). Control of these bodies is given by design to individuals who, regardless of their commitment to quality postsecondary education, cannot make decisions based on direct knowledge of academia. Moreover, they come predominantly from the business sector.

This overrepresentation of external members seems to arise from the misconception that positioning external to the core functions of the university is synonymous with independent thinking. However, whether members are external or internal does not speak to whether they are truly independent, or have the ability to focus on the common good of the university. The naïve assumption that professors, students and support staff represent specific interests, and are therefore incapable of seeing the general interest of the organization as whole, both demonizes internal members and idealizes external ones. In fact, this marginalization of professors, students, and support staff appears to be antagonistic to the very idea of collegial governance that is understood as characteristic of the academic environment. Such a misguided viewpoints rests on the contested premise that management is a set of technical instruments, practices, and knowledge that are universal and timeless, regardless of the specifics of a given organization (Alvesson, Bridgman \& Willmott, 2009). Management becomes generic, and disconnected from its organizational context. This perspective authorizes managers to focus on abstract categories, financial ratios, performance target and indicators, all articulated through balanced scorecards, which are no

\footnotetext{
${ }^{6}$ See: http://web5.uottawa.ca/admingov/comite_3.html
} 
longer understood as partial and subjective representations of the organization's complexity, but considered to be the comprehensive and objective expression of organizational performance.

In the end, managerialism and professionalization go hand in hand. Harney \& Moten (2013) explain this logic as part of the "professionalization" specific to contemporary universities: "the university works for the day when it will be able to rid itself, like capital in general, of the trouble of labor. It will then be able to reproduce a labor force that understands itself as not only unnecessary but dangerous to the development of capitalism" (Harney \& Motten, 2013, p. 29). Needless to say, all of this is in sharp contrast to the democratic university, which will be addressed in the next section.

\section{The Democratic Horizon of the Contemporary University}

According to Amy Gutmann, the democratic university provides "an institutional sanctuary against repression" that may help to counteract attempts at "controlling the creation of politically relevant ideas" (1987, p. 179). By searching for and disseminating ideas and knowledge independently, the university provides the public with resources essential for critique, debate and mobilization. ${ }^{7}$ It is crucial to the democratic university's mandate to provide the public with these critical resources that faculty have the academic freedom to think and express themselves independently, critically, and without interference. ${ }^{8}$ It is therefore worth examining academic freedom as a site of contestation between managerial and democratic perspectives on university governance. We do this by comparing the Canadian Association of University Teachers' (CAUT) Statement on Academic Freedom (2011) with the Association of Universities and Colleges of Canada's (AUCC) Statement on Academic Freedom (2011).

CAUT's mandate is "to promote the interests of Academic staff, including, but not limited to, professors, professional librarians and researchers, to advance the standards of their professions, and to seek to improve the quality of post-secondary education in Canada" (CAUT, 2014). AUCC aims to be "the voice of Canada's Universities." It is comprised of "97 public and private not-for-profit Canadian universities" and is "governed by a board of directors consisting of university presidents" (AUCC, 2015). Although the

\footnotetext{
${ }^{7}$ This is even more important in contexts where governments shut down major research facilities and muzzle government scientists for ideological reasons. For examples of the Canadian federal government doing this under Stephen Harper's Conservatives, see Turner (2013).

${ }^{8}$ Of course, as noted by Richard Hofstadter, "academic freedom is a modern term for an ancient idea $[\ldots]$ its continuous history is concurrent with the history of universities since the twelfth century" (Hofstadter, 1955, p. 3, quoted in Horn, 1999, p. 4). However, with variations among states, it was not until the $19^{\text {th }}$ and $20^{\text {th }}$ centuries that academic freedom became more solidly institutionalized. The progress of academic freedom was largely dependent on the institution of tenure and the unionization of professors. In Canada, this progress mostly appeared in the second half of the $20^{\text {th }}$ century (Horn, 1999), but is increasingly under assault.
} 
CAUT's statement conforms to the idea of a democratic university, that of the AUCC has far more to do with the hierarchical perspective of the managerial university.

CAUT's statement is divided into six sections, which are worth reviewing individually. The first section defines the primary mission of post-secondary institutions: they "serve the common good of society through searching for, and disseminating, knowledge and understanding and through fostering independent thinking and expression in academic staff, and students," and are an essential condition in establishing "robust democracies" (CAUT, 2011). The section concludes by stressing that "these ends cannot be achieved without academic freedom" (CAUT, 2011). Two key points need to be emphasized. First, academic freedom is crucial in ensuring that colleges and universities can fulfill their basic missions to support research and the dissemination of knowledge and understanding via teaching and community service, and thus advance the common good of society, including a strong democracy. Second, institutions must do more than merely tolerate academic freedom; they also have a responsibility to foster "independent thinking and expression" (i.e., promote and protect academic freedom against infringement by dominant powers) (CAUT, 2011).

The second section of CAUT's statement defines academic freedom as follows:

Academic freedom includes the right, without restriction by prescribed doctrine, to freedom to teach and discuss; freedom to carry out research and disseminate and publish the results thereof; freedom to produce and perform creative works; freedom to engage in service to the institution and the community; freedom to express one's opinion about the institution, its administration, and the system in which one works; freedom to acquire, preserve, and provide access to documentary material in all formats; and freedom to participate in professional and representative academic bodies. Academic freedom always entails freedom from institutional censorship. (CAUT, 2011)

The definition makes four main points. First, it indicates that academic freedom is a right "without restriction by prescribed doctrine" (CAUT, 2011) - a right that must be interpreted broadly. Second, it emphasizes that academic freedom encompasses all activities that are part of the three overarching missions of post-secondary institutions: teaching and discussion; research and creative works; and community service beyond the institution. In this sense, academic freedom encompasses the right to "fulfill one's professional obligations" (Turk, 2014b, p. 11). By contrast, the AUCC's (2011) statement gives a narrower and more individualist definition of academic work by omitting any mention of community service. Third, CAUT's definition lists freedoms that are complementary to the first freedom, including the "freedom to express one's opinion about the institution, its administration, and the system in which one works" (CAUT, 2011). Such freedom allows for debate and criticism relating to the direction 
educational institutions take. Here again, the AUCC (2011) statement provides a narrower definition by not including such complementary freedoms. Fourth, CAUT's definition emphasizes that academic freedom "always entails freedom from institutional censorship" (CAUT, 2011), reminding us that colleges and universities are power structures that can threaten academic freedom. By comparison, the AUCC's statement (2011) does not recognize that colleges and universities themselves can be a danger to academic freedom, suggesting that threats could only be external.

In the managerial university attacks on academic freedom often come from its administration, especially when the public image of the business-oriented institution is assumed to suffer from criticisms expressed by professors. For example, in May 2014, Robert Buckingham, Dean of the School of Public Health and full professor at the University of Saskatchewan, was expeditiously fired for publicly criticizing changes announced by the senior management of his university. In a letter titled "The Silence of the Deans," Buckingham revealed that he was threatened with dismissal if he publicly criticized the reform plans or the decision-making process at his institution:

In December 2013 the President of the University of Saskatchewan called a meeting of the Senior Leadership Team (Deans and Vice-Presidents) to discuss the TransformUs process. Her remarks were to the point: she expected her senior leaders to not "publicly disagree with the process or findings of TransformUs"; she added that if we did our "tenure would be short." With that meeting there was the 'silence of the deans.' Never in my 40 years of academic life have I seen academics being told that they could not speak out and debate issues. Although the initial publicly released TransformUs documents were vague, behind closed doors the President and Provost planned major changes to our School of Public Health, all the while warning me against discussing any of these proposals with my faculty and students. Deans were also told that when the final recommendations were released we had to support them with faculty, students and the public, even if we disagreed with them. (Robert Buckingham, quoted in CBC News Saskatoon, May 14-15, 2014)

In the dismissal letter signed by the university's Vice-President Academic, we learn that among the reasons Buckingham was fired was for having "damaged the reputation of the university" (CBC News Saskatoon, May 14$15,2014)$. Judging by the outcry over this decision and by the revelations made by Buckingham, it is arguably the behaviour of the senior administration of the university that tainted the reputation of the institution. Senior management later reinstated Buckingham as full professor, but not as Dean of the School of Public Health. The message is clear: professors who assume major administrative responsibilities ought to relinquish their freedom to debate and criticize the decisions of their institution. This is a hierarchical and authoritarian view of the university, with senior management making key decisions, controlling information, and standing together in order to limit debate and contestation. In such a context, it is not only Robert Buckingham's academic freedom that was infringed upon, it is the freedom 
of all faculty, students, and staff who were denied a well-informed debate over major transformations taking place at their institution. This example illustrates how academic freedom can be threatened in two distinct ways: through the decision-making process and by the decisions taken via this process.

Section Three of the CAUT statement stresses that "academic freedom does not require neutrality on the part of the individual"; rather "academic freedom makes intellectual discourse, critique, and commitment possible" without fear of "reprisal or repression by the institution, the state, or any other another source" (CAUT, 2011). This should be the case regardless of whether academic freedom is explicitly or implicitly included in collective agreements or employment contracts. By comparison, a managerial view tends to confine professors to the role of neutral experts.

The fourth section of the CAUT's statement emphasizes that academic staff "must not be hindered or impeded in exercising their civil rights as individuals including the right to contribute to social change through free expression of opinion on matters of public interest," and they should not suffer institutional reprisals for exercising such rights (CAUT, 2011). Again, there is nothing about this in the AUCC's statement on academic freedom.

Section Five addresses the link between academic freedom and institutional governance. It states that "academic freedom requires that academic staff play a major role in the governance of the institution" and "shall constitute at least a majority on committees or collegial governing bodies responsible for academic matters including but not limited to curriculum, assessment procedures and standards, appointment, tenure and promotion" (CAUT, 2011). As we discussed earlier, academic personnel are a minority on the University of Ottawa's Senate, its governing body responsible for academic matters. Although stating that "it is a major responsibility of university governing bodies and senior officers to promote and protect academic freedom," the AUCC's statement on academic freedom (2011) is silent about professors' participation, as well as about the principle of collegiality that should be the driving force of such governing bodies. We will return to the participatory dimension of academic freedom below.

The sixth and final section of the CAUT's statement insists that "academic freedom must not be confused with institutional autonomy" (CAUT, 2011). Having defined the autonomy of institutions as the ability to "set policies independent of outside influence," the statement emphasizes that such autonomy is a double-edged sword: it can indeed "protect academic freedom from a hostile external environment, but it can also facilitate an internal assault on academic freedom" (CAUT, 2011). Furthermore, Section Six reminds readers that "academic freedom is a right of members of the academic staff, not of the institution" and that "the employer shall not abridge academic freedom on any grounds, including claims of institutional autonomy" (CAUT, 2011). By comparison, the AUCC's statement (2011) embraces a one-sided view of institutional autonomy as protecting academic 
freedom against external threats. Despite recent examples like Robert Buckingham's, the AUCC's statement has not been modified to recognize that post-secondary institutions themselves may constitute a threat to academic freedom.

Notwithstanding the six sections described above, the CAUT's statement does not cover all angles of the debate on academic freedom. For example, it does not say much about the academic freedom of students, on potential conflicts of freedoms, or on the limits of academic freedom. ${ }^{9}$ Nevertheless, an analysis of the CAUT's statement helps emphasize that any weakening of academic freedom lowers the capacity of the university to significantly contribute to democratic debate. By contrast, the AUCC's statement neglects to mention the university's democratic role as a vector of critical thinking.

Another major difference between the CAUT and AUCC statements is that, while the former does not mention anything explicit about the limits of academic freedom, the latter stresses "the responsibilities of academic freedom" (AUCC, 2011). Indeed, the AUCC's statement emphasizes that faculty must follow "the professional standards of the relevant discipline" and claims that it is the university leadership's responsibility to ensure "that academic freedom is exercised in a reasonable and responsible manner" (AUCC, 2011). In the current context of the managerialization of postsecondary institutions, the AUCC's focus on the responsibilities of academic freedom is more a reflection of senior management's hierarchical view and willingness to control faculty - and to punish them when they do not comply - than a response to unreasonable and irresponsible exercises of academic freedom by academic staff.

Moreover, the heavy emphasis on disciplinary norms is problematic in many ways. First, as Mark Gabbert (2014) points out, strict adherence to disciplinary norms is necessary to gain membership in academia. From the beginning to the end of their quest for membership, aspiring academics must please "undergraduate teachers, graduate advisors, and dissertation committees; followed by hiring committees and tenure committees; and promotion committees; and peer reviewers of work; and all this in synergistic combination with the norms of granting agencies" (Gabbert, 2014, p. 96). In such a context, "there is little danger of producing too many closet enthusiasts of intelligent design" in the academia; the result is more likely to be "the production of anxious careerists who, to paraphrase past AAUP [American Association of University Professors] President Cary Nelson's complaint, are too preoccupied with meeting the norms to participate in collegial governance" (Gabbert, 2014, p. 96). This is especially likely in a context in which all university strata "have grown accustomed to the saturation of university life by neoliberal rationality, metrics, and principles of governance" (Brown, 2015, p. 198). Second, as Joan Scott emphasizes, the relationship between disciplinary norms and academic freedom is a complex

${ }^{9}$ For more on these questions, see Menand (1996), Nelson (2010), and Turk (2014a). 
and paradoxical one: "disciplinary communities provide the consensus necessary to justify academic freedom as a special freedom for faculty. But the inseparable other side of this regulatory and enabling authority is that it can suppress innovative thinking in the name of defending immutable standards" (Scott, 2014, p. 115). In light of this, the AUCC's emphasis on the responsibility to follow disciplinary norms is at best ill-advised. At worse, it may be a way to use disciplinary norms for controlling and punishing 'disobedient' professors.

Finally, it is important to note that the CAUT's statement establishes a strong link between academic freedom and the democratic governance of universities. Section Five of the statement emphasizes that "academic freedom requires that academic staff play a major role in the governance of the institution" (CAUT, 2011), meaning that academic freedom contains a dimension of democratic participation that guarantees its integrity. The bearers of these rights to academic freedom should normally be those who are best qualified to respect and defend academic freedom through a collegial governance model in which they have a strong presence. In contrast, managerialism prioritizes centralized decision-making, hierarchical and authoritarian management, the proliferation and professionalization of administrators, a culture of secrecy and superficial consultations. In the latter model of governance, academic freedom and the voices of professors and students are considered impediments to the 'normal' operations of the organization - and are usually poorly dealt with by professionalized administrations, as exemplified by the Buckingham case - rather than as vital components of a democratic institution. The quality of discussions and decisions, as well as their legitimacy, are significantly depleted (Fearon, 1998). This vision has a trickle-down effect on hiring processes, types of preferred research, career paths of professors, and even educational content. Academic managerialism, which first implies a top-down management practice related to particular values (profitability), is gradually established as a mode of subjectivization that tends to fundamentally transform the nature of the university community. By not even mentioning the principle of collegiality and the participation of academic staff in the governance of postsecondary institutions, the AUCC's statement on academic freedom (2011) supports the managerial university model.

\section{Conclusion: A Possibility for Change?}

Over the last decade, the Canadian university has been under siege from managerialism, to the point of eroding its democratic and collegial governance, as well as challenging the very foundations of academic freedom. In the case of the University of Ottawa, the method for appointing members to the Board of Governors and to the Senate is itself conducive to managerialism, and helps explains the lack of representation from many 
stakeholders in the university community. Unicameralism and multicameralism, when it comes to a university's main decision-making bodies, are neither a guarantor of improved representation of stakeholders, nor can they ensure an effective, fair, and equitable decision-making process. Such a process is also shaped by many other variables, including the composition and number of members of the assembly, the method in which they are appointed, the term of their mandate, their re-eligibility, the frequency and dynamics of meetings, and the transparency and accessibility of information relevant to deliberation and the decision-making process.

By comparing the Canadian Association of University Teachers' (CAUT) Statement on Academic Freedom (2011) with the Association of Universities and Colleges of Canada's (AUCC) Statement on Academic Freedom (2011), we have seen how the managerialism inspiring the latter leads to a narrow view of academic work and academic freedom. For example, while the CAUT's statement stresses the collegial participatory dimension of academic freedom and establishes a strong link between academic freedom and the democratic governance of universities, the AUCC's statement is silent about professors' participation, as well as about the principle of collegiality that should be the driving force of democratic governance. Similarly, while the CAUT's statement emphasizes academic freedom as freedom to think critically and freedom from institutional censorship, reprisal, and repression (CAUT, 2011), the AUCC's statement fails to recognize the university's democratic responsibility as a vector of critical thinking, puts heavy emphasis on disciplinary norms, and does not consider that post-secondary institutions may themselves be a threat to academic freedom.

As long as full- and part-time professors, support staff, and students remain marginalized on the Board of Governors and the Senate no change of vision or strategic direction seems possible. The overrepresentation of university administrators and a business-oriented clique, which fails to represent the diversity of the university's community or the context of teaching and research, can only maintain and extend the managerialization of the institution. Moreover, lack of faculty representation and participation in university governance is detrimental to academic freedom, denying the collegial participatory component that is an essential part of the principle. In other words, the 'de-managerialization' of the University of Ottawa, like other Ontario universities, clearly represents a long-term mission. We think that building the conditions for appropriate representation for faculty, staff, and students in universities' decision-making bodies is a crucial site of political struggle for a democratic university. Since representation is closely linked to academic freedom, which is the backbone of the democratic university in practice, we think that unions, associations, departments, and individuals in university communities need to mobilize in order to make targeted and concrete gains on this terrain.

Although the experience of rising managerialism during the 1990s in the Canadian federal and provincial public sectors can teach us some lessons for 
managerialism's implementation in academia, it is not a substitute for critical social research on the university sector itself. In particular, we should seek to build critical knowledge of the contemporary university by (a) studying academic managerialism's influence on pedagogy and on student experience more broadly, (b) assessing the evolution of working conditions in relation to participation in the governance of Canadian universities in the past 30 years, and (c) documenting and analyzing the frequency and types of academic freedom incidents in Canadian universities in the last decade. We think that the case of the University of Ottawa is a telling example of the ongoing managerialism at play in Canadian universities. We also believe that change in academia can only come through a better and more critical understanding of universities' governance, beginning with (but not limited to) the central institutions of the Board of Governors and the University Senate.

\section{Acknowledgements}

The authors would like to thank the anonymous reviewers for their comments and suggestions, which contributed helpfully to the final version of the paper. They would also like to thank the editors for their generous comments and support during a highly constructive review process.

\section{References}

Alvesson, M., Bridgman, T., \& Willmott, H. (Eds.). (2009). The Oxford handbook of critical management studies. Oxford: Oxford University Press.

AUCC (Association of Universities and Colleges of Canada) (now Universities Canada). (2011). Statement on academic freedom. Retrieved from http://www.univcan.ca/media-room/newsand-commentary/canadas-universities-adopt-new-statement-on-academic-freedom/

AUCC (Association of Universities and Colleges of Canada). (2015). About us: Membership and governance. Retrieved from http://www.univcan.ca/about-us/membership-and-governance/

Bissonnette, L., \& Porter, J.R. (2013). L'Université québécoise : Préserver les fondements, engager des refondations. Quebec City: Government of Quebec. Retrieved from http://www.mesrs.gouv.qc.ca/fileadmin/administration/librairies/documents/chantiers/Chan tierLoiCadreDesUniversites.pdf

Brown, W. (2015). Undoing the demos: Neoliberalism's stealth revolution. New York: Zone Books.

CAUT (Canadian Association of University Teachers). (2011). CAUT policy statements: Academic freedom. Retrieved from http://www.caut.ca/about-us/caut-policy/lists/cautpolicy-statements/policy-statement-on-academic-freedom

CAUT (Canadian Association of University Teachers). (2014). CAUT by-law number 1 . Retrieved from http://www.caut.ca/docs/default-source/by-law/caut-by-law-number-1(2014-11)6e8c33f1c6ef6d389810ff00005eecd3.pdf?sfvrsn=2

CBCnews Saskatoon (2014, May 14-15). Prof. Robert Buckingham fired after criticizing Saskatchewan university plan. Retrieved from http://www.cbc.ca/news/canada/saskatoon/prof-robert-buckingham-fired-after-criticizingsaskatchewan-university-plan-1.2642637

Chan, A.S., \& Fisher, D. (2008). The exchange university: Corporatization of academic culture. Toronto: UTP Press.

Studies in Social Justice, Volume 9, Issue 2, 142-158, 2015 
Côté, J.E., \& Allahar, A. (2011). Lowering higher education: The rise of corporate universities and the fall of liberal education. Toronto: University of Toronto Press.

Côté, M., Day, R.J., \& de Peuter, G. (Eds.). (2007). Utopian pedagogy: Radical experiments against neoliberal globalization. Toronto: University of Toronto Press.

Council of Ontario Universities. (2012). Interprovincial comparison of university revenues. Retrieved from http://cou.on.ca/papers/interprovincial-comparison-of-university-revenue/

Council of Ontario Universities. (2011). Innovative ideas: Improving efficiency at Ontario universities. Retrieved from http://www.cou.on.ca/publications/reports/pdfs/innovativeideas---improving-efficiency-at-ontario

Enteman, W.F. (1993). Managerialism: The emergence of a new ideology. Madison, WI: University of Wisconsin Press.

Exworthy, M., \& Halford, S. (Eds.). (1999). Professionals and the new managerialism in the public sector. Buckingham, UK: Open University Press.

Fearon, J.D. (1998). Deliberation as discussion. In J. Elster (Ed.), Deliberative democracy (pp. 44-68). Cambridge: Cambridge University Press.

Gabbert, M.A. (2014). The right to think otherwise. In J.L. Turk (Ed.), Academic freedom in conflict: The struggle over free speech rights in the university (pp. 89-109). Toronto: James Lorimer.

Ginsberg, B. (2011). The fall of the faculty: The rise of the all-administrative university and why it matters. Oxford: Oxford University Press.

Giroux, D., \& Karmis, D. (Eds.). (2015). Introduction to Défaire/refaire l'université: Essai de tout dire. Les Cahiers de l'idiotie, 6.

Government of Ontario. (1965). The University of Ottawa Act, S.O. 1965, C.137. Retrieved from http://web5.uottawa.ca/www4/emarket/dev/admingov/university-act.html

Gutmann, A. (1987). Democratic education. Princeton: Princeton University Press.

Harney, S., \& Moten, F. (2013). The undercommons: Fugitive planning and Black study. Brooklyn, NY: Autonomedia.

HEQCO (2015). The Ontario University Funding Model in Context. Retrieved from http://www.heqco.ca/SiteCollectionDocuments/Contextual\%20Background $\% 20$ to $\% 20$ the $\%$ 20Ontario\%20University\%20Funding\%20Formula-English.pdf

Hofstadter, R. (1955). The age of the college. In R. Hofstadter \& W.P. Metzger (Eds.), The development of academic freedom in the United States (pp. 1-274). New York: Columbia University Press.

Horn, M. (1999). Academic freedom in Canada: A history. Toronto: University of Toronto Press.

Hudon, P.-A., \& Rouillard, C. (2015). Critical management studies (CMS) and public administration: Reinterpreting democratic governance using critical theory and poststructuralism. Canadian Public Administration, 58(4), 527-548.

Menand, L. (Ed.). (1996). The limits of academic freedom. In L. Menand (Ed.), The future of academic freedom (pp. 3-20). Chicago: The University of Chicago Press.

Mills, N. (2012). The corporatization of higher education. Dissent Magazine (Fall issue). Retrieved from http://www.dissentmagazine.org/article/the-corporatization-of-highereducation

Nelson, C. (2010). No university is an island: Saving academic freedom. New York: New York University Press.

OCUFA (2015) Budget 2015 continues erosion of public funding for Ontario universities. Retrieved from http://ocufa.on.ca/blog-posts/politics/budget-2015-continues-erosion-ofpublic-funding-for-ontario-universities/

Pollitt, C., \& Bouckaert, G. (2011). Public management reform: A comparative analysis - New public management, governance, and the neo-Weberian state. Oxford: Oxford University Press.

Readings, B. (1996). The university in ruins. Cambridge: Harvard University Press.

Rouillard, C. (2003). From cynicism to organizational disillusion: New public management as confusing factor. Choices, Institute for Research on Public Policy (IRPP), 9(6), 20-38.

Rouillard, C., \& Giroux, D. (2005). Public administration and the managerialist fervour for values and ethics: Of collective confusion in control societies. Administrative Theory and Praxis - ATP, 27(2), 330-357. 
Scott, J.W. (2014). The limits of academic freedom. In J.L. Turk (Ed.), Academic freedom in conflict: The struggle over free speech rights in the university (pp. 110-123). Toronto: James Lorimer.

Turk, J.L. (Ed.). (2000). The corporate campus: Commercialization and the dangers to Canada's colleges and universities. Toronto: James Lorimer.

Turk, J.L. (Ed.). (2014a). Academic freedom in conflict: The struggle over free speech rights in the university. Toronto: James Lorimer.

Turk, J.L. (2014b). Introduction. In J.L. Turk (Ed.), Academic freedom in conflict: The struggle over free speech rights in the university (pp. 11-20). Toronto: James Lorimer.

Turner, C. (2013). The war on science: Muzzled scientists and wilful blindness in Stephen Harper's Canada. Vancouver: Greystone Books. 